\title{
The Urban Law Program of the University of Detroit School of Law
}

\author{
Norman L. Miller* and James C. Daggitt**
}

$\mathrm{T}^{\mathrm{s}}$

HERE HAS RECENTLY BEEN a muttering of dissatisfaction on the part of many lawyers and legal educators which has steadily grown into a decidedly discomfiting rumble. In some cases it is the result of an awareness of the rigidity and pedantic, if not atrophic, qualities which exemplify the majority of curricula in the nation's law schools, both large and small; in other cases it has arisen because law schools seem to be preparing their students only for roles as desk lawyers, and closing their eyes to the urgency of new social and economic patterns which have begun to exert such insistent pressures that they can no longer be ignored. ${ }^{1}$ More often than not, the two expressions are actually two different ways of looking at the same problem, namely, when will law schools recognize and reflect in changed curricula the changing needs of changing times?

In September 1965 the University of Detroit School of Law received a grant of 242,000 dollars from the Office of Economic Opportunity. The grant provides funds for a demonstration, research, and training program under Title II-A of the Economic Opportumity Act of $1964 .^{2}$

Prior to receipt of this grant the law school reexamined its course of study, similar to that of practically all other U.S. law schools, and found it inconsistent with the realities of modern society, but, more particularly, based on a limited perspective of the role of the attorney in society. It was safely traditional, saleable, and consistent with the image that far too many lawyers have of the profession. It was also uncomfortably unsuited to our times and to the demands to be made on future lawyers.

* A.B., 1957, LL.B., 1960, University of Michigan; Cert. M.S., 1961, Wayne State University. Assistant Dean and Associate Professor of Law, Director of the Urban Law Program, University of Detroit School of Law.

* B.A., 1953 Amherst College; LL.B., 1964, University of Michigan. Member, D.C. Bar.

1 See, e.g., Reich, Toward the Humanistic Study of Law, 74 YALE L.J. 1402, 1406-07 (1965): "Many of the ills of legal education are symptomatic of the fact that it is primarily professional in orientation, although it should also be preparing students for lives of public service and scholarship. ... . [T]lie most important reason for a new approach to the study of law is not simply to improve the present job of educating scholars, public servants, and practitioners as that job is now conceived. The ultimate justification for curricular revision, or rather the necessity, comes from the fact that the role of law in society has changed and is changing, and hence the role of lawyers must change. Iaw now permeates every activity. This trend is inevitable as society rapidly becomes more institutional and bureaucratic. Today's social problems necessarily becoune legal problems."

278 Stat. 508, 516, 42 U.S.C. $\$ \S 2781-91$ (1964). 


\section{I}

\section{THE URBAN COMMUNITY AND THE LAW}

It appears eminently clear that American life patterns, public and private, personal and collective, will revolve around the urban community. These centers, containing millions of inhabitants, stretching hundreds of miles, will require the development of new legal relationships of an infinite variety. New concepts will be needed for urban governmental units creating ties of various kinds between the metropolitan center and the outlying suburban areas. No longer will there be simply a dependency on the center city's water supply, public transportation systems, and freeways. The immediate future will create dependencies on the complete range of planning and service expertise found in the center city which the outlying areas cannot afford or would be financially foolish to duplicate. Intelligent land use planning is essential.

It is also clear that city governments are beginning to challenge and, in many cases, to eclipse state governments in importance as a means through which federal programs may be effected. State capitals have not been particularly responsive or particularly sensitive to the needs of the large metropolitan areas within their borders. Cooperative city administrations are providing a more appealing local forum for the exercise of national pohicy. With the continually increasing urbanization of America's population, it is not surprising that the city should prove a more effective instrumentality for reaching the people.

There is a need to develop new legal concepts and attitudes in both public and private arenas. As the development of city-federal ventures continues, lawyers will create the units defining these relationships and their modus operandi. The development of cooperative and condominium housing requires lawyers to develop a new scheme of private riglits and obligations. Attorneys representing private clients must keep up with the certain growth of public and administrative law. Better yet, they ought to participate in its development, to aid in its architecture. But to do this, the future lawyers must have an understanding of what and who will be involved in the urban centers of the future.

Urban law in both its public and private sectors is where law schools ought to be giving their attention now. But to do so requires an analysis, an understanding of the past and present. It requires, equally so, a fostering and nurturing of the idealism that first year students have that somehow manages to wither and decay as graduation approaches. One suspects that this disappearance of idealism results from a continuous three-year diet of case method instruction; unsensible and static rules of law, a realization of the inadequacies of the legal system and of the direct rela- 
tionship between the quality of American legal service and the client's ability to pay.

Ought not law students also to be exposed to a developmental approach or method of legal studies? Have law schools forgotten that all their graduates do not become advocates of special interests?

The University of Detroit School of Law has chosen to enter the field of Urban Law. An examination of the legal problems of the urban poor brings the panorama of the entire urban society into focus. The lawyers serving the urban poor, the legal researchers accumulating law course materials dealing with the urban poor, preparing educational materials on legal topics for dissemination among the urban poor, or researching the legal problems which might be uniquely associated with the urban poor (public assistance law, landlord-tenant, government contracts, property, criminal law) of necessity must examine the entire life and structure of the metropolitan area. These are not problems in isolation. The legal nature of the urban political structure, its courts, and agencies must be known and understood.

II

THE DETROIT URBAN LAW PROGRAM

Situated as it is in the heart of the inner city of one of the country's great industrial areas, the University of Detroit School of Law is located in an area that might wryly be described as ideal for the study of the problems of urban poverty. From a window of the law school one can see both high-rise luxury apartments built on urban renewal land and skidrow ghettos. The concept of the Urban Law Program and the work toward its implementation have therefore a vital and intense immediacy.

The program involves four interrelated elements. The first is the restructuring of the law school curriculum and its extracurricular activities to focus on the legal problems of the poor as well as to deal with the legal issues arising out of urban situations. This will eventually include courses leading to graduate degrees in law, not previously offered.

The second element is the initiation of a community education program aimed at familiarizing the general community with the legal rights and services available to them.

The third component is a clinical experience for law students which will have the fourfold effect of making available additional legal help for the indigent, giving students invaluable practical opportunities to learn the operations of our legal system, exposing them to the daily problems of the urban poor, and bringing into the academic isolation of law school studies the concept of a legal intern program where practical application can be made of classroom knowledge. 
The fourth element is a research program, not fully implemented at the time of writing, aimed at: (1) gathering information on the legal problems of the poor and the particular city in which they live; (2) legal research to provide the content for curriculum development and community education; (3) evaluation of the clinical program and study of the experience developed there; (4) study and drafting of legislation where appropriate; and (5) the development of an interdisciplinary approach to both urban law and the law school curriculum.

A number of new law courses have been proposed, and others have already been made part of the curriculun. Among those proposed are courses in public assistance law, urban property law, employee rights, and legal and social problems of juveniles in the urban community. Already instituted and part of the curriculum are a trial seminar, the academic compamion of the chinical experience, aimed at giving the students the training they need to interview chents, prepare pleadings, and try cases, and an interdisciplinary law and poverty seminar. In the latter course, economists, sociologists, criminologists, psycloologists, psychiatrists, and urban planners, anong others, participate in the objectives of giving law students a thorough grounding in the many dimensions of the problems of urban life and the urban poor, and revealing the programs and assistance that other disciplines and the community have developed for the solution of nonlegal problems that will inevitably accompany the client of the future lawyer. Supplementary materials for the so-called traditional courses are also in preparation, designed to make the traditional courses more useful to the lawyer who intends to practice in the urban community.

As previously mentioned, plans are in process for introducing a Graduate Program in Urban Law. The field of urban law sorely needs specialists, both as practitioners and teachers. It takes years of practical experience to accumulate the specialized knowledge which can be acquired in a few well-conceived courses. With most law schools devoting so little time to courses relevant to urban practice; specialized education in this field must cone at the graduate level. Such a program will culminate in an intensive internship for those who plan to become practitioners, including working as an attorney in the Urban Law Office or some other agency offering a similar experience. For those in the graduate program who wish to teach, a thesis requirement will be substituted for a part of the internship.

A law school which purports to be a law school for the urban community cannot confine its efforts to the select few who aspire to become lawyers. It also has an obligation to the total community it serves to instill in the members of the urban community an understanding of their rights and responsibilities under the law. The urban poor, in particular, 
often are abused by the legal process because they are ignorant of even the most elementary of its principles. They frequently submit to illegal acts and baseless legal claims because they do not realize the law provides the grounds and forum with which to resist.

This Community Education Program phase of the Urban Law Program has been extremely active and will undoubtedly become more so as the word spreads. Already, legal counseling and services have been sought by and given to tenants' councils, homeowners' groups, and the local Community Action Program of the Office of Economic Opportumitycalled TAAP (Total Action Against Poverty) in Detroit. Students in the Program have lectured widely and often in junior and senior high schools, telling the young audiences of their legal rights and advising them, for example, what to do and what not to do in the case of an arrest.

The third pliase of the Program, involving chinical experience for the law student has, to date, been the most vital and active part of the plan. The Urban Law Office of the University of Detroit was opened in November 1965 in a store front building one-half block from the law school. It is in an area which is also within walking distance of the courts and the jails, and close to some of the most depressed neighborhoods of the city. The Law Office, fully staffed, has three full-time attorneys, two neighborhood people working as investigators, a social worker, clerical staff; and between thirty and fifty participating students from the second and third year classes.

The place has a highly kinetic atmosphere, with a steady flow of people seeking and getting the help they need. If it is found that a chent is able to pay legal fees, he is referred to a local lawyer on the Urban Law Office's reference hist. If he does not have money for fees, he qualifies for help at the Urban Law Office. There are no restrictions on the types of cases handled.

The response to the Law Office has been so enthusiastic that there are more than seven hundred files now in the office. The effectiveness of the Law Office as a service to the urban poor remains to be seen and will not be known until a considerable amount of data can be gathered and evaluated over a period of time. There can be no doubt, however, that with such a response, there is a tremendous need for the services. Nor can there be much doubt that the young men and women who have participated as legal interns in the program have gained much from their experience, even in the few months that the Law Office has been open.

The fourth and final aspect of the program, the research aspect, is still in a highly formative state. Not until there has been time to collect and evaluate data will the research project make its major contribution to the Urban Law Program. The research section lias, however, done 
considerable work in legislative drafting with regard to the proposed Michigan Housing Code of 1966.

\section{CONCLUSION}

That the problem of the emerging lawyer has become one of wide interest is manifestly shown by the widely different forums in which the problem has been discussed. From the article by Martin Mayer in the popular Saturday Evening Post to a plethora of writings in law journals, similar ideas emerge: Law schools are not doing their job, law curricula are static, the product of most law schools is an individual primed mainly to take his place perhaps in the courtroom, or more likely only in the world of commerce. As Charles Reich has aptly stated:

Until very recently the legal profession has narrowly limited its scope. Lawyers have traditionally concerned themselves with only one sector of the world in which law now operates, the sector of commerce. For most of them, day-to-day law has meant business law. Other problems have clustered around the business core, but these have also tended to be commercial in nature. Today, however, it is vitally necessary that lawyers actively participate in all of the areas of society in which law now plays a role. Their work may start with business, but it should range over criminal law, public housing, social welfare, unemployment, problems of the mentally ill, urban town and country planning, economic planning both local and national, civil rights, civil liberties, all forms of protest movements, and international law. In their private capacity they should be available to help all those individuals and groups who come in contact with law. They should learn to represent the various imterest groups, constituencies and minorities in societyto help them develop points of view, speak for them, and interpret the world to them. That is the true scope of the practicing lawyer's calling. ${ }^{4}$

A large order? Indeed it is. But we feel that our Urban Iaw Program, both in its concept and in its execution, can answer that large order. The answer will arise out of the fact that the law school curriculum will, for the first time; give the law student direct experience with the problems of the urban community. A new dimension will be added by making, so to speak, the community a classroom. Perhaps in this way, the much quoted phrase of Oliver Wendell Holmes that "the life of the law has not been logic: it has been experience," will finally have an application in the life of our law students.

The rest remains to be written in the next few years. Our hopes, in addition to our aims, are high.

${ }^{3}$ Mayer, Justice, The Law and the Lawyer, The Saturday Evening Post, Feb. 26, 1966, pp. $36,72$.

4 Reich, supra note 1 , at 1407 .

5 Holmes, The Comaron Law 1 (Howe Ed. 1881). 


\section{California Law Review}

\begin{tabular}{lll} 
VoL. 54 & No. 2 \\
\hline
\end{tabular}

BOARD OF EDITORS

\begin{tabular}{|c|c|}
\hline & $\begin{array}{l}\text { GGAR } \\
\text { ef } \\
\text { Is III } \\
\text { tor }\end{array}$ \\
\hline $\begin{array}{c}\text { FREDERICK INNES Fox } \\
\text { Article Editor }\end{array}$ & $\begin{array}{c}\text { D. КетTH BLTER } \\
\text { Head Note \& Comment Editor }\end{array}$ \\
\hline $\begin{array}{l}\text { ROBERT W. STEDMAAN } \\
\text { Article Editor }\end{array}$ & $\begin{array}{l}\text { GoRdon I. Grabaix } \\
\text { Note \& Comment Editor }\end{array}$ \\
\hline $\begin{array}{l}\text { RICEAED L. JAEGER } \\
\text { Research Editor }\end{array}$ & $\begin{array}{c}\text { Geratd E. MULLEN } \\
\text { Note \& Comment Editor }\end{array}$ \\
\hline $\begin{array}{l}\text { JOEN CONRAD FossOAS } \\
\text { Book Review Editor }\end{array}$ & $\begin{array}{l}\text { DougLas R. REYNoLdS } \\
\text { Note \& Comment Editor }\end{array}$ \\
\hline $\begin{array}{c}\text { LEE J. SCLAR } \\
\text { Associate Editor }\end{array}$ & $\begin{array}{c}\text { DLANA S. Stoppetio } \\
\text { Note \& Comment Editor }\end{array}$ \\
\hline
\end{tabular}

Research Board

DENMIS M. EAGAN

Larry Braxton Dent Loyd PAXTon Derby

ROBERT H. BERGER JerRy J. BERMcaN Robert ALAN BLUAT Alan G. CarLton Grorge Cumarng ToM A. Dowse MICHAEx A. FISCBER DAVID B. FroHNMAYYeR Dantex S. Frost Barbara Brudno Gardner KENNETH A. GoLDMaAN
THEODORE J. ENGLAND

\section{Associates}

KENNEY F. HEGLAND EDWIN N. LOWE, JR.

\section{Candidates}

Donatd S. Greenderg STEPEEN H. GREENLEAF Martin E. Harband ALEXANDER M. HeERTEYer Robert Cart Herr Daljas Holmes RICEARD C. HUNT STEVEN M. KIPPERALAN David ALAN LEXzZIGER EDMund R. Manweld Richard S. Platz

Marjorte Devereux Administrative Assistant
RODOLFo ḾMONTEJANo

Clifford K. Thompson, Jr. DAVID M. WIISON

NordaA ERNEST REITZ WIIIAMM T. RINTALA SeIvya Setoex Cart J. Seneker II Myron G. SUgaracaN SANDra TerzIan GarY E. Thaceer Tract A. Westen StandeY H. WutuaMS Cearles Wison Ketry C. Wooster 